for

\title{
Acidic Hydrolysis of $N$-ethoxybenzylimidazoles (NEBIs): Potential Applications as pH-Sensitive Linkers for Drug Delivery
}

\author{
Seong Deok Kong, ${ }^{\dagger}$ Alice Luong, ${ }^{\dagger}$ Gerald Manorek, ${ }^{\ddagger}$ Stephen B. Howell, ${ }^{\ddagger}$ and Jerry \\ Yang $^{\dagger, *}$
}

$\dagger$ Department of Chemistry and Biochemistry, University of California, San Diego, 9500 Gilman Drive, La Jolla CA 92093-0358, and $\$$ Department of Medicine and the Rebecca and John Moores Cancer Center, University of California, San Diego, 3855 Health Sciences Drive, MC 0819, La Jolla, 92093 


\section{General Comments}

All reagents were purchased from Sigma-Aldrich, Inc., TCI, or Alfa Aesar and used without further purification. Doxorubicin (AKA Adriamycin) was from Bedford Laboratories. NMR spectra were recorded on a Varian $400\left(\right.$ FT, $400 \mathrm{MHz},{ }^{1} \mathrm{H} ; 100 \mathrm{MHz}$, $\left.{ }^{13} \mathrm{C}\right)$ spectrometer. HRMS (high-resolution mass spectra) were obtained in the Department of Chemistry \& Biochemistry, University of California, San Diego. Kinetic analysis by reverse-phase high performance liquid chromatography (RP-HPLC) was performed with a Agilent 1100 Series HPLC using an analytical reverse-phase column (SPHERI-5 Phenyl 5 micron, 250 x $4.6 \mathrm{~mm}$ ).

\section{General Procedure for the synthesis of $N$-ethoxybenzylimidazoles (1-8)}

A solution of benzaldehyde $(6.82 \mathrm{mmol})$, triethyl orthoformate $(3.3 \mathrm{~g}, 22.5 \mathrm{mmol})$, and conc. $\mathrm{HCl}(10 \mu \mathrm{L}, 90 \mu \mathrm{mol})$ was refluxed in $3.7 \mathrm{~mL}$ of ethanol for $24 \mathrm{hrs}$. Diethyl ether was added and the organic layer was extracted with $2 \mathrm{M} \mathrm{NaOH}$. The organic layer was dried over anhydrous $\mathrm{Na}_{2} \mathrm{SO}_{4}$. After removal of diethyl ether under reduced pressure, the crude mixture was distilled under vacuum $\left(55-65{ }^{\circ} \mathrm{C} / 0.5 \mathrm{mmHg}\right)$ to give pure benzaldehyde diethylacetal $\left(82-91 \%\right.$ yield). All acetals were characterized by ${ }^{1} \mathrm{H}-\mathrm{NMR}$ and used without further purification.

A mixture of imidazole $(1.0 \mathrm{~g}, 14.7 \mathrm{mmol})$, benzaldehyde diethylacetal $(58.8$ mmol), and $p$-toluenesulfonic acid ( $84 \mathrm{mg}, 0.441 \mathrm{mmol})$ was heated neat at $110{ }^{\circ} \mathrm{C}$ for 1 3 days, accompanied by concurrent distillation of ethanol. After cooling, sodium carbonate $(0.47 \mathrm{~g}, 4.41 \mathrm{mmol})$ was added and the crude mixture was distilled under 
vacuum $\left(150-170{ }^{\circ} \mathrm{C} / 0.5 \mathrm{mmHg}\right)$ to give $N$-ethoxybenzylimidazole derivatives (1-8) (15$75 \%$ yield).

Characterization of 1: ${ }^{1} \mathrm{H}$ NMR $\left(\mathrm{CDCl}_{3}, 400 \mathrm{MHz}\right) 1.258(\mathrm{t}, 3 \mathrm{H}), 3.539(\mathrm{~m}, 2 \mathrm{H})$, 6.178 (s, $1 \mathrm{H}), 6.955$ (s, $1 \mathrm{H}), 7.078$ (s, $1 \mathrm{H}), 7.290-7.327$ (m, $5 \mathrm{H}), 7.673(\mathrm{~s}, 1 \mathrm{H}) ;{ }^{13} \mathrm{C}$

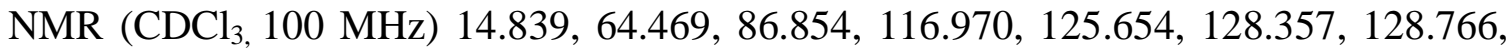
129.647, 136.249, 137.616; HRMS $(m / z)$ calcd for $\mathrm{C}_{12} \mathrm{H}_{14} \mathrm{~N}_{2} \mathrm{O}\left(\mathrm{M}^{+}\right)$, 202.1101; found, 202.1102.

Characterization of 2: ${ }^{1} \mathrm{H}$ NMR $\left(\mathrm{CDCl}_{3,} 400 \mathrm{MHz}\right) \delta 1.254(\mathrm{t}, 3 \mathrm{H}), 3.523(\mathrm{~m}, 2$ H), 6.136 (s, 1 H), 6.920 (s, 1 H), 7.091 (s, 1 H), 7.177 (d, 2 H), 7.474 (d, 2 H), 7.673 (s, $1 \mathrm{H}) ;{ }^{13} \mathrm{C} \mathrm{NMR}\left(\mathrm{CDCl}_{3}, 100 \mathrm{MHz}\right) \delta 14.954,64.686,86.308,116.948,123.043,127.563$, 130.088, 131.631, 136.398, 136.885; HRMS $(\mathrm{m} / z)$ calcd for $\mathrm{C}_{12} \mathrm{H}_{13} \mathrm{BrN}_{2} \mathrm{O}\left(\mathrm{M}^{+}\right)$, 280.0206; found, 280.0207 .

Characterization of 3: ${ }^{1} \mathrm{H}$ NMR $\left(\mathrm{CDCl}_{3}, 400 \mathrm{MHz}\right) \delta 1.297(\mathrm{t}, 3 \mathrm{H}), 3.573(\mathrm{~m}, 2$ H), $6.268(\mathrm{~s}, 1 \mathrm{H}), 6.927$ (s, 1 H), $7.132(\mathrm{~s}, 1 \mathrm{H}), 7.506$ (d, 2 H), 7.724 (s, $1 \mathrm{H}), 8.217$ (d, $2 \mathrm{H}) ;{ }^{13} \mathrm{C} \mathrm{NMR}\left(\mathrm{CDCl}_{3}, 100 \mathrm{MHz}\right) \delta 14.979,65.019,85.813,116.881,123.804,127.031$, 130.682, 136.535, 144.476, 148.155; HRMS $(\mathrm{m} / z)$ calcd for $\mathrm{C}_{12} \mathrm{H}_{13} \mathrm{~N}_{3} \mathrm{O}_{3}\left(\mathrm{M}^{+}\right), 247.0951$; found, 247.0954. 
Characterization of 4: ${ }^{1} \mathrm{H} \mathrm{NMR}\left(\mathrm{CDCl}_{3}, 400 \mathrm{MHz}\right) \delta 0.902(\mathrm{t}, 3 \mathrm{H}), 1.260(\mathrm{t}, 3 \mathrm{H})$, $1.322(\mathrm{~m}, 2 \mathrm{H}), 1.562$ (m, $2 \mathrm{H}), 2.588$ (t, $2 \mathrm{H}), 3.547$ (m, $2 \mathrm{H}), 6.162$ (s, $1 \mathrm{H}), 6.974$ (s, 1 H), 7.085 (s, $1 \mathrm{H}), 7.157$ (d, $2 \mathrm{H}), 7.211$ (d, $2 \mathrm{H}), 7.677$ (s, $1 \mathrm{H}) ;{ }^{13} \mathrm{C} \mathrm{NMR}\left(\mathrm{CDCl}_{3}, 100\right.$ MHz) $\delta 13.998,14.882,22.346,33.539,35.324,64.428,86.955,116.981,125.596$, 128.392, 129.707, 135.003, 136.274, 143.633; HRMS $(\mathrm{m} / \mathrm{z})$ calcd for $\mathrm{C}_{16} \mathrm{H}_{22} \mathrm{~N}_{2} \mathrm{O}\left(\mathrm{M}^{+}\right)$, 258.1727; found, 258.1728 .

Characterization of 5: ${ }^{1} \mathrm{H}$ NMR $\left(\mathrm{CDCl}_{3}, 400 \mathrm{MHz}\right) \delta 1.258(\mathrm{t}, 3 \mathrm{H}), 3.583(\mathrm{~m}, 2$ H), 6.417 (s, 1 H), 6.959 (s, 1 H), 7.049 (s, 1 H), 7.218 (t, 1 H), 7.370 (t, 1 H), 7.536 (d, 1 H), $7.645(\mathrm{~d}, 1 \mathrm{H}), 7.701(\mathrm{~s}, 1 \mathrm{H}) ;{ }^{13} \mathrm{C} \mathrm{NMR}\left(\mathrm{CDCl}_{3}, 100 \mathrm{MHz}\right) \delta$ 14.874, 64.754, 85.960, $116.979,122.396,127.356,127.605,129.400,130.410,132.916,136.490,136.632$; HRMS ( $m / z)$ calcd for $\mathrm{C}_{12} \mathrm{H}_{13} \mathrm{BrN}_{2} \mathrm{O}\left(\mathrm{M}^{+}\right)$, 280.0206; found, 280.0203 .

Characterization of 6: ${ }^{1} \mathrm{H}$ NMR $\left(\mathrm{CDCl}_{3}, 400 \mathrm{MHz}\right) \delta 1.253$ (t, $\left.3 \mathrm{H}\right), 3.549(\mathrm{~m}, 2$ H), 3.747 (s, $1 \mathrm{H}), 6.472$ (s, $1 \mathrm{H}), 6.841$ (d, $1 \mathrm{H}), 6.966-7.340$ (m, $4 \mathrm{H})$, 7.638-7.667 (m, 2 $\mathrm{H}) ;{ }^{13} \mathrm{C} \mathrm{NMR}\left(\mathrm{CDCl}_{3}, 100 \mathrm{MHz}\right) \delta 15.257,55.762,64.738,82.219,110.872,117.093$, 120.806, 126.206, 126.532, 129.261, 130.293, 136.770, 156.288; HRMS $(\mathrm{m} / z)$ calcd for $\mathrm{C}_{13} \mathrm{H}_{16} \mathrm{~N}_{2} \mathrm{O}_{2}\left(\mathrm{M}^{+}\right)$, 232.1206; found, 232.1209.

Characterization of 7: ${ }^{1} \mathrm{H} \mathrm{NMR}\left(\mathrm{CDCl}_{3}, 400 \mathrm{MHz}\right) \delta 1.300(\mathrm{t}, 3 \mathrm{H}), 3.664(\mathrm{~m}, 2$ H), 6.491 (s, 1 H), 7.059 (s, 1 H), 7.127 (s, 1 H), 7.450-7.546 (m, 2 H), 7.615-7.706 (m, 2 
$\mathrm{H}), 7.763(\mathrm{~s},, 1 \mathrm{H}) ;{ }^{13} \mathrm{C}$ NMR $\left(\mathrm{CDCl}_{3}, 100 \mathrm{MHz}\right) \delta 14.926,65.643,85.159,111.088$, $116.643,117.062,126.209,129.568,130.139,133.254,136.386,141.222 ;{ }^{13} \mathrm{C}$ NMR (Acetone- $\left.d_{6}, 100 \mathrm{MHz}\right) \delta 14.495,65.035,84.882,111.161,116.563,117.125,126.592$, $129.744,129.846,133.435,133.606,137.071,141.789$; HRMS $(\mathrm{m} / \mathrm{z})$ calcd for $\mathrm{C}_{13} \mathrm{H}_{13} \mathrm{~N}_{3} \mathrm{O}\left(\mathrm{M}^{+}\right), 227.1053$; found, 227.1055.

Characterization of 8: ${ }^{1} \mathrm{H}$ NMR $\left(\mathrm{CDCl}_{3}, 400 \mathrm{MHz}\right) \delta 1.213(\mathrm{t}, 3 \mathrm{H}), 3.583(\mathrm{~m}, 2$ H), 6.907 (s, $1 \mathrm{H}), 7.030$ (s, $1 \mathrm{H}), 7.134$ (s, $1 \mathrm{H}), 7.289$ (d, $1 \mathrm{H})$, 7.517-7.627 (m, $2 \mathrm{H})$, $7.725(\mathrm{~s},, 1 \mathrm{H}), 7.933(\mathrm{~d}, 1 \mathrm{H}) ;{ }^{13} \mathrm{C} \mathrm{NMR}\left(\mathrm{CDCl}_{3}, 100 \mathrm{MHz}\right) \delta$ 14.683, 65.873, 83.735, $117.508,125.062,127.500,130.140,130.241,132.873,133.443,136.940,148.102$; HRMS ( $/ \mathrm{m} / \mathrm{z})$ calcd for $\mathrm{C}_{12} \mathrm{H}_{13} \mathrm{~N}_{3} \mathrm{O}_{3}\left(\mathrm{M}^{+}\right)$, 247.0951; found, 247.0950.

\section{Synthesis of $N$-ethoxybenzylimidazole-doxorubicin conjugate (9)}

We synthesized compound $\mathbf{9}$ using a synthetic route outlined in Scheme S1.

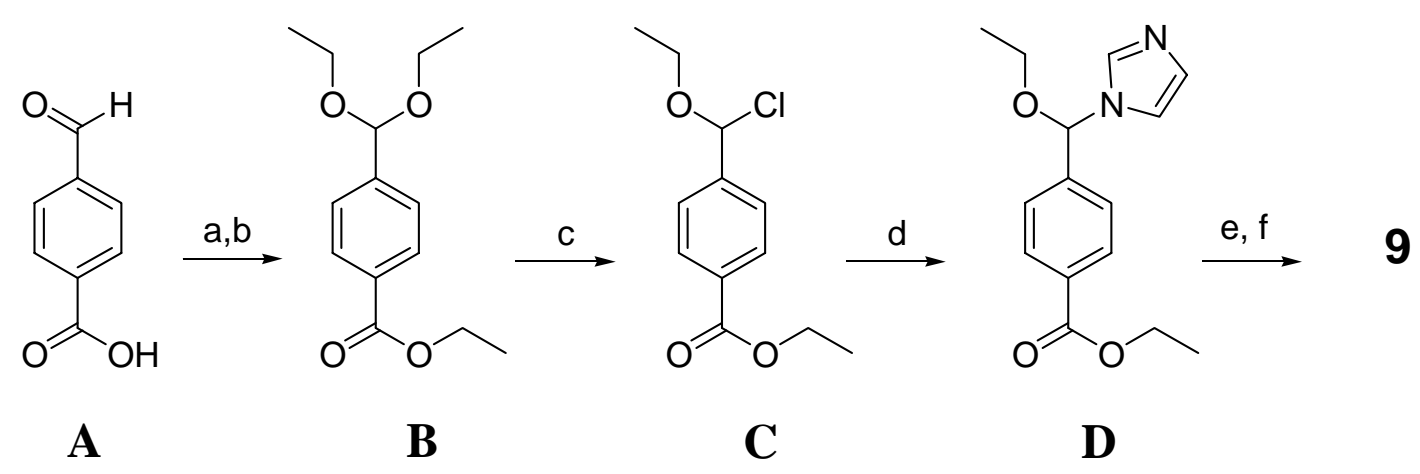


Scheme S1. Synthetic scheme for $N$-ethoxybenzylimidazole-doxorubicin conjugate 9. Reagents: a) $\mathrm{SOCl}_{2}$, ethanol; b) triethyl orthoformate, $\mathrm{HCl}$, ethanol, $78 \%$ yield for two steps; c) $\mathrm{SOCl}_{2}, \mathrm{HOAc}$, neat; d) $\mathrm{NaH}$, imidazole, THF, $33 \%$ yield for two steps; e) $\mathrm{NaOH}, \mathrm{THF} / \mathrm{H}_{2} \mathrm{O}, 90 \%$ yield; f) doxorubicin, EDC, THF, $54 \%$ yield.

4-carboxylbenzaldehyde (A) (13.5 mmols) and thionyl chloride (27 mmols) was refluxed in $50 \mathrm{~mL}$ anhydrous dichloromethane (DCM) and $20 \mathrm{~mL}$ distilled ethanol for 12 hours. An additional $3 \mathrm{~mL}$ of thionyl chloride $(41 \mathrm{mmols})$ was added and the solution was allowed to reflux for another 24 hours. The solution was cooled and the solvents were removed under reduced pressure. The product mixture was dissolved in DCM and washed with $10 \%$ sodium bicarbonate. The organic layer was dried over anhydrous $\mathrm{Na}_{2} \mathrm{SO}_{4}$. Crude NMR indicated a mixture of $\mathbf{B}$ and ethyl 4-formylbenzoate and was taken on without further purification.

The crude mixture of $\mathbf{B}$ and ethyl 4-formylbenzoate was combined with triethyl orthoformate $(44.5 \mathrm{mmol})$ and conc. $\mathrm{HCl}(19.5 \mu \mathrm{L}, 178 \mu \mathrm{mol})$ in $2.59 \mathrm{~mL}$ of absolute ethanol and allowed to reflux for 24 hours. After removal of ethanol and excess orthoformic acid under reduced pressure, the crude mixture was taken up in diethyl ether and the solution was washed with $2 \mathrm{M} \mathrm{NaOH}$. The organic layer was dried over anhydrous $\mathrm{Na}_{2} \mathrm{SO}_{4}$, and the diethyl ether was removed under reduced pressure. Compound $\mathbf{B}$ was distilled from the crude mixture under vacuum $\left(141^{\circ} \mathrm{C}, 0.7\right.$ Torr $)$ to give pure compound (78\% isolated yield from A). Characterization of $\mathbf{B}:{ }^{1} \mathrm{H}$ NMR $\left(\mathrm{CDCl}_{3}, 400 \mathrm{MHz}\right) \delta 1.170(\mathrm{t}, 6 \mathrm{H}), 1.318(\mathrm{t}, 3 \mathrm{H}), 3.481(\mathrm{~m}, 4 \mathrm{H}), 4.295(\mathrm{q}, 2 \mathrm{H}), 5.476(\mathrm{~s}$, 
1H), $7.478(\mathrm{~d}, 2 \mathrm{H}), 7.969(\mathrm{~d}, 2 \mathrm{H}){ }^{13} \mathrm{C} \mathrm{NMR}\left(\mathrm{CDCl}_{3}, 100 \mathrm{MHz}\right) \quad \delta$ 14.465, 15.316, 61.157, 100.956, 126.834, 129.587, 130.526, 144.045, 166.411 ESI-MS: $224.96\left(\mathrm{M}^{+}\right.$ethyl), 206.99 ( $\mathrm{M}^{+}$- ethoxy).

The synthesis of $\mathbf{C}$ was performed in using a modified procedure as previously reported (1). A solution of $\mathbf{B}(1.13 \mathrm{mmol})$, freshly distilled acetyl chloride $(1.8 \mathrm{mmol})$ and thionyl chloride $(0.227 \mathrm{mmol})$ was refluxed for one hour under $\mathrm{N}_{2}$. The excess thionyl chloride and acetic acid were removed under reduced pressure and the crude mixture was characterized by ${ }^{1} \mathrm{H}$ NMR. ${ }^{1} \mathrm{H}-\mathrm{NMR}$ (in $\mathrm{CDCl}_{3}$ ) indicated a new peak at $\delta=$ $6.203 \mathrm{ppm}$, presumably corresponding to the benzylic $\mathrm{H}$ in $\mathbf{C}$. The crude yield of $\mathbf{C}$ by ${ }^{1} \mathrm{H}-\mathrm{NMR}$ was $\sim 54 \%$, with the remainder of the material identified as starting material $\mathbf{B}$ $(\sim 8 \%)$ as well as a large amount $(\sim 38 \%)$ of ethyl 4 -formylbenzoate. The crude material was immediately taken on to the next step without further purification. Note: we observed hydrolysis of $\mathbf{C}$ (presumably with moisture in the air) over the course of several hours when left open to air. Compound $\mathbf{C}$ should, therefore, be prepared fresh and used immediately.

In a dry flask, $\mathrm{NaH}(0.612 \mathrm{mmol})$ and imidazole $(0.612 \mathrm{mmol})$ was allowed to stir for one hour in $0.5 \mathrm{~mL}$ of anhydrous THF. A solution of a crude mixture of $\mathbf{C}(0.612$ mmols) was added to the imidazole solution. The solution was stirred for 12 hours at 23 ${ }^{\circ} \mathrm{C}$. After removal of the solvent under reduced pressure, $\mathbf{D}$ was isolated by silica chromatography using as eluent a 95:5 mixture of DCM:methanol. The isolated yield of D was 33\%. Characterization of E: ${ }^{1} \mathrm{H}$ NMR $(\mathrm{MeOH}, 400 \mathrm{MHz}) \delta 1.270(\mathrm{t}, 3 \mathrm{H}), 1.368$ (t, 3H), $3.526(\mathrm{~m}, 1 \mathrm{H}), 3.674(\mathrm{~m}, 1 \mathrm{H}), 4.358(\mathrm{q}, 2 \mathrm{H}), 6.527(\mathrm{~s}, 1 \mathrm{H}), 7.089(\mathrm{~d}, 2 \mathrm{H}), 7.509$ (d, 2H), $7.946(\mathrm{~s}, 1 \mathrm{H}), 8.034(\mathrm{~d}, 2 \mathrm{H}) .{ }^{13} \mathrm{C} \mathrm{NMR}(\mathrm{MeOH}, 100 \mathrm{MHz}) \delta$ 15.621, 15.158, 
$62.349,65.760,87.583,118.570,127.252,129.949,130.777,132.216,138.103,144.535$, 167.464 ESI-MS: $274.54\left(\mathrm{M}+\mathrm{H}^{+}\right)$

A solution of the $\mathbf{D}(0.151 \mathrm{mmol})$ and $\mathrm{LiOH}(0.151 \mathrm{mmol})$ in $0.8 \mathrm{~mL}$ of a $5: 3$ tetrahydrofuran (THF):water solution was allowed to stir for $12 \mathrm{hrs}$ at $23{ }^{\circ} \mathrm{C}$. The THF and water were removed under reduced pressure and the crude solid was washed with chloroform. ${ }^{1} \mathrm{H}-\mathrm{NMR}$ of the crude in $\mathrm{CD}_{3} \mathrm{OD}$ indicated only the desired carboxylate was present (presumably as the lithium salt). The yield was estimated as $90 \%$ by weight.

The crude mixture from ester hydrolysis of $\mathbf{D}(.134 \mathrm{mmol})$ was dissolved in 1.5 $\mathrm{mL}$ dimethylformamide (DMF). Doxorubicin (16.7 $\mu \mathrm{mol})$ and 1-(3dimethylaminopropyl)-3-ethylcarbodiimide hydrochloride (EDC, 66.8mmol) were added to the DMF solution and stirred for 12 hours at $23{ }^{\circ} \mathrm{C}$. Product 9 was isolated by silica chromatography using as eluent a 92:8 mixture of DCM:methanol. The isolated yield of 9 was 54\%. Characterization of 9: ${ }^{1} \mathrm{H}$ NMR $(\mathrm{MeOH}, 400 \mathrm{MHz}) \delta 1.242(\mathrm{t}, 3 \mathrm{H}), 1.283$ (m, 6H), $1.833(\mathrm{~d}, 1 \mathrm{H}), 2.136(\mathrm{~m}, 2 \mathrm{H}), 2.356(\mathrm{~d}, 1 \mathrm{H}), 2.915(\mathrm{~d}, 1 \mathrm{H}), 3.017(\mathrm{~d}, 1 \mathrm{H}), 3.491$ (m, 1H), $3.635(\mathrm{~m}, 1 \mathrm{H}), 3.741(\mathrm{~s}, 1 \mathrm{H}), 3.955(\mathrm{~s}, 3 \mathrm{H}), 4.326(\mathrm{t}, 2 \mathrm{H}), 4.753(\mathrm{~d}, 2 \mathrm{H}), 5.069$ (s, 1H), $5.435(\mathrm{~s}, 1 \mathrm{H}), 5.492(\mathrm{~s}, 1 \mathrm{H}), 6.471(\mathrm{~s}, 1 \mathrm{H}), 6.990(\mathrm{~s}, 1 \mathrm{H}), 7.081(\mathrm{~s}, 1 \mathrm{H}), 7.433(\mathrm{~m}$, $3 \mathrm{H}), 7.740\left(\mathrm{t}, 1 \mathrm{H} 0,7.809(\mathrm{~d}, 3 \mathrm{H}), 7.885(\mathrm{~s}, 1 \mathrm{H})\right.$. HRMS $(\mathrm{m} / \mathrm{z})$ calcd for $\mathrm{C}_{40} \mathrm{H}_{42} \mathrm{O}_{13} \mathrm{~N}_{3}$ $\left(\mathrm{M}+\mathrm{H}^{+}\right)$772.2712; found, 772.2721.

\section{Synthesis of $N$-(4-formylbenzoyl)doxorubicin (10)}

Doxorubicin $(6.9 \mu \mathrm{mol})$ was stirred in $660 \mu \mathrm{L}$ of acetonitrile and $340 \mu \mathrm{L}$ of water. 4 carboxybenzaldehyde $(13.8 \mu \mathrm{mol})$, and EDC $(17.6 \mu \mathrm{mol})$ were added to the solution and 
the solution was stirred for 18 hours at $23{ }^{\circ} \mathrm{C}$. Product $\mathbf{1 0}$ was isolated by silica chromatography using as eluent a 90:10 mixture of DCM:methanol. The isolated yield of 10 was $51 \%$.

Characterization of 10: ${ }^{1} \mathrm{H}$ NMR $\left(\mathrm{CDCl}_{3}, 300 \mathrm{MHz}\right) \quad 1.341(\mathrm{~s}, 3 \mathrm{H}) \quad 1.873(\mathrm{~d}, 1 \mathrm{H})$, 2.004(m, 2H), $2.172(\mathrm{~d}, 1 \mathrm{H}), 2.227(\mathrm{~d}, 1 \mathrm{H}), 2.353(\mathrm{~d}, 1 \mathrm{H}), 3.103(\mathrm{~d}, 1 \mathrm{H}), 3.301(\mathrm{~d}, 1 \mathrm{H})$, $3.760(\mathrm{~s}, 1 \mathrm{H}), 4.266(\mathrm{~m}, 1 \mathrm{H}), 4.788(\mathrm{~s}, 3 \mathrm{H}), 5.337(\mathrm{~d}, 1 \mathrm{H}), 5.556(\mathrm{~d}, 1 \mathrm{H}), 6.519(\mathrm{~d}, 1 \mathrm{H})$, $7.416(\mathrm{~d}, 1 \mathrm{H}), 7.800(\mathrm{t}, 1 \mathrm{H}), 7.919(\mathrm{~m}, 5 \mathrm{H}), 8.051(\mathrm{~d}, 1 \mathrm{H}), 10.064(\mathrm{~s}, 1 \mathrm{H}) . \quad$ ESI-MS: $698.01\left(\mathrm{M}+\mathrm{Na}^{+}\right)$

\section{General procedure for hydrolysis of $N$-ethoxybenzylimidazole derivatives (1-8)}

$1-8(0.05 \mathrm{mmol})$ were placed in $0.5 \mathrm{~mL}$ of $0.5 \mathrm{M} 2$-[N-morpholino]ethanesulfonic acid (MES) buffer $(\mathrm{pH}=5.5)$ or $\quad 0.5 \quad \mathrm{M} \quad \mathrm{N}$-[2-hydroxyethyl]piperazine-N'-[2ethanesulfonic acid] (HEPES) buffer $(\mathrm{pH}=7.4)$ containing 20-40\% DMSO- $d_{6}(\mathrm{v} / \mathrm{v})$ and incubated at $37{ }^{\circ} \mathrm{C}$ in a constant temperature bath. The rates of hydrolyses were obtained

by ${ }^{1} \mathrm{H}-\mathrm{NMR}$ measurements. The relative ${ }^{1} \mathrm{H}$ NMR integrations of the benzylic protons of 1-8 and the aldehyde proton of the benzaldehyde product resulting from hydrolysis were compared over the time in order to estimate the rate of hydrolysis for the $\mathrm{N}$ ethoxybenzylimidazoles.

\section{Hydrolysis of $N$-ethoxybenzylimidazole conjugated with Doxorubicin (9)}

The $N$-ethoxybenzylimidazole conjugated with Doxorubicin (9) $(0.37 \mu \mathrm{mol})$ was dissolved in $0.5 \mathrm{~mL}$ of $18.6 \mathrm{mM}$ MES buffer $(\mathrm{pH}=5.5)$ or $18.6 \mathrm{mM}$ HEPES buffer $(\mathrm{pH}=7.4)$ containing $30 \%$ DMSO (v/v) and incubated at $37{ }^{\circ} \mathrm{C}$ in a constant temperature bath. The hydrolysis of 9 at $\mathrm{pH}=5.5$ and $\mathrm{pH}=7.4$ was monitored by RP-HPLC by 
injection of small aliquots $(20 \mu \mathrm{L})$ of the solutions at regular time intervals and analyzing the chromatograms at $\lambda=470 \mathrm{~nm}$. The products were eluted with an isocratic solvent mixture of $70 \% \mathrm{MeOH}$ and $30 \% \mathrm{H}_{2} \mathrm{O}$ with a flow rate of $1 \mathrm{~mL} / \mathrm{min}$. The retention time of $\mathbf{9}$ and $\mathbf{1 0}$ were 6.25 minutes and 8.11 minutes, respectively. We determined the rates of hydrolysis of the $\mathrm{N}$-ethoxybenzylimidazole moiety in $\mathbf{9}$ by comparison of the relative integrated HPLC peak areas of $\mathbf{9}$ and $\mathbf{1 0}$ at each time point.

\section{Cytotoxicity studies of (10) on human ovarian carcinoma 2008 cells}

Human ovarian carcinoma 2008 cells were plated in 6-well plates at a density of 200 cells in $3 \mathrm{~mL}$ of media (RPMI-1640 + 10\% Fetal Bovine Serum) per well and incubated overnight to allow the cells to adhere to the bottom of the wells. After overnight incubation the media was removed from each well and fresh growth media containing different concentrations of $\mathbf{1 0}$ was added to the wells. The cells were incubated for 1 hour in the presence of $\mathbf{1 0}$. Following the removal of the solutions containing 10, the cells were incubated with fresh media for 10 days to allow surviving cells to form colonies. After removal of media, the plates were washed with $2 \mathrm{~mL}$ of room temperature PBS buffer $(\mathrm{pH} 7.4,0.138 \mathrm{M} \mathrm{NaCl}, 0.003 \mathrm{mM} \mathrm{KCl}, 14.2 \mathrm{mM}$ potassium phosphate), and then fixed and stained for 15 minutes with $1 \mathrm{~mL}$ of $0.1 \%$ crystal violet solution that contains $10 \%$ methanol. Clusters containing $>50$ cells were scored as colonies using an AlphaInontech Imager. We performed this colony formation assay in triplicate on 3 independent occasions. 
(1) Capon, B., Nimmo, K. (1975) General acid-catalyzed hydrolysis of benzaldehyde aryl methyl acetals J. Chem. Soc., Perkin Trans. 2, 10, 1113-1118. 

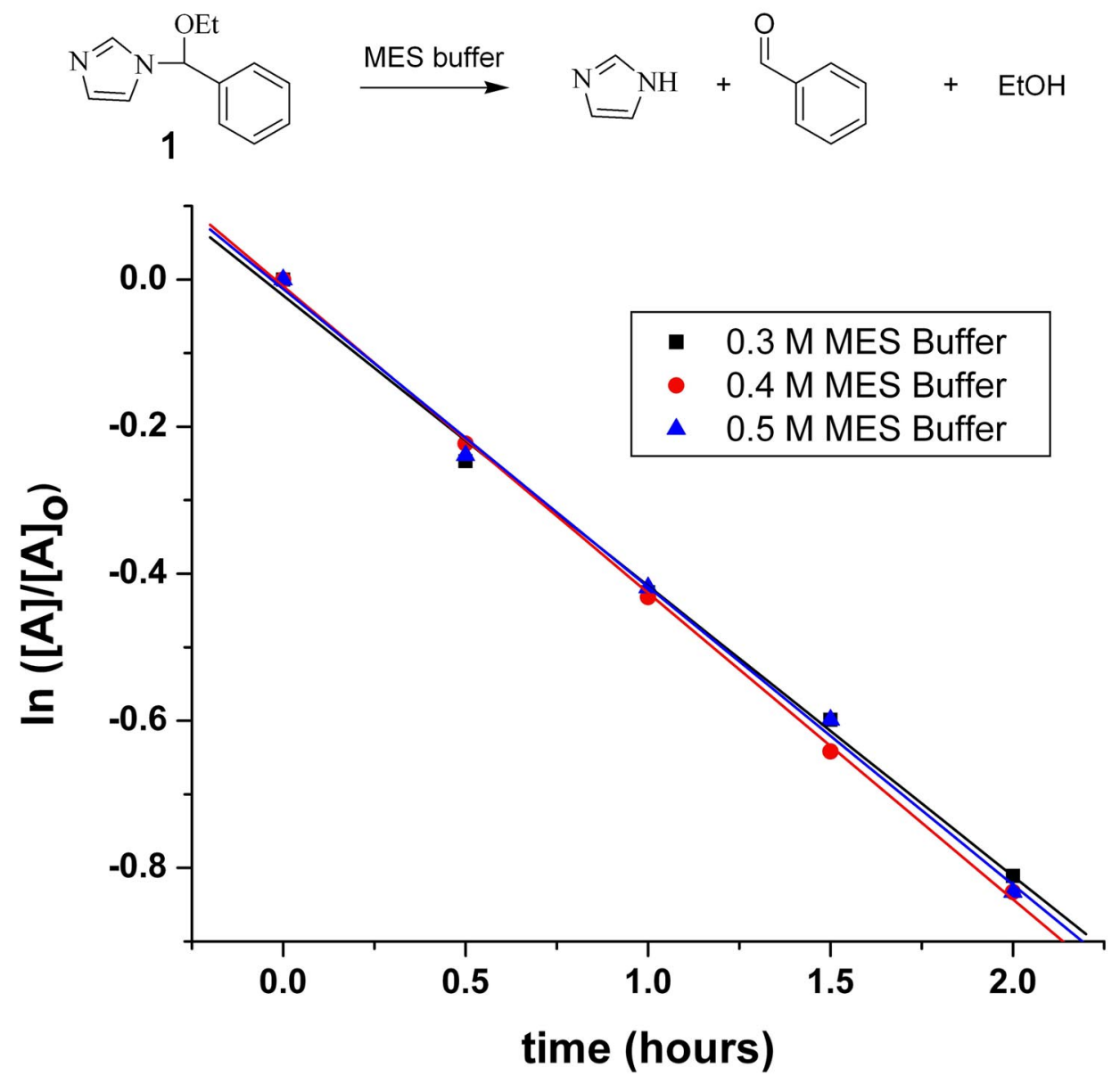

Figure S1. The dependence of the concentration of MES buffer on the rates of hydrolysis of $\mathrm{N}$-ethoxybenzylimidazole 1. $\mathrm{NaCl}$ was added to solutions containing less than $0.5 \mathrm{M}$ MES buffer to maintain a constant ionic strength for all measurements. Solutions of $\mathbf{1}$ $(50 \mathrm{mM})$ in buffered $\mathrm{D}_{2} \mathrm{O}$ solutions containing $20 \% d_{6}$-DMSO $(\mathrm{v} / \mathrm{v})$ were incubated in a $37^{\circ} \mathrm{C}$ constant temperature bath. Rates of hydrolyses were obtained by ${ }^{1} \mathrm{H}-\mathrm{NMR}$ (400 $\mathrm{MHz}$ ) measurements. 